\title{
A Study on Environmental Literacy Levels of Social Studies Teacher Candidates
}

\author{
Mavi AKKAYA YILMAZ1 \\ Aydın Adnan Menderes University, AYDIN, TURKEY
}

${ }^{1}$ Corresponding author: Assist. Prof. Dr.. Aydın Adnan Menderes University, Faculty of Education, Department of Social Studies Education, Efeler /Aydın, TURKEY. mavi.akkaya [at] adu.edu.tr. ORCID: 0000-0003-3005-9559

\begin{abstract}
This study aims to determine the environmental literacy levels of Social Studies teacher candidates. In the study, an explanatory sequential design was used, which is one of the mixed research designs. The participants of the study are Social Studies teacher candidates who are studying at two state universities in Turkey during the 2020-2021 academic year. 152 teacher candidates participated in the quantitative part of the research, while 12 teacher candidates participated in the qualitative part of the research. The data was collected using the Environmental Literacy Survey prepared by Karatekin (2011) and also a semi-structured interview developed by the researcher. Percentage, frequency, independent groups T-test, Mann-Whitney-U test, one-factor variance analysis (ANOVA) and the KruskalWallis test were used in the analysis of the data. As a result of the analysis, it was determined that the teacher candidates were moderately environmentally literate, and their environmental literacy levels did not vary according to class and gender. Social Studies teacher candidates most often defined environmental literacy by providing information on the theme of heritage. In addition, teacher candidates mentioned they use resources such as articles, books, and magazines to improve their environmental literacy skills. In addition, teacher candidates mentioned they experienced a number of difficulties gaining their environmental literacy skills due to the impact of education, family and society. Considering the research results in general, it can be said that it would be useful to focus on environmental issues within educational and training activities.
\end{abstract}

\section{Keywords}

Social Studies Teacher Candidate, Environment, Environmental Literacy 
Today, information is changing rapidly. The task of transferring this change to students within education and training activities falls on teachers. For this reason, teachers should give their students the opportunity to acquire a number of skills that they will need throughout their life. At this point, students equipped with such skills will be able to overcome the difficulties in their lives more easily and become better equipped to meet the requirements of the age.

All living things have an environment "the environment is the external environment in which living things that live on Earth maintain their relationships throughout their lives" (Özey, 2009, p. 22). So "everything but genetics is environment." (Güler \& Vaizoğlu, 2011, p.12). From this point of view, all living and inanimate beings around humans, even space, fall into the concept of the environment (Roth, 1968, p.4). Based on this, the environment can be considered in a narrow and broad sense. In a narrow sense, the environment is where a creature has the ability to move. In a broad sense, it is the area in which a creature is indirectly or directly affected or affected. At this point, it can be said that all the environments in which living things live, from a nest or house to the entire world, are the environment (Özey, 2009, p. 7) It can be noted that people also relate to this environment in different dimensions and levels.

Since its existence, human beings have constantly lived intertwined with nature, benefited from it, fought against it and tried to control all the forces of nature. A very cruel struggle between humans and nature caused large-scale destruction on plants, animals and the air, which would also damage humans (Ergün, 2019, p. 111). In addition, due to factors caused by humanity such as urbanization, rapid population growth, developing technology and industry, a range of environmental problems have increased and these problems have started to threaten human life (Akıllı \& Genç, 2015, p.82). Therefore, it is important to give people the opportunity to have access to environmental education in order to raise awareness about the environment and create a sustainable environment.

Environmental education emerged as a separate field in the mid-1960s and benefits from many disciplines including natural resource conservation education, nature education, resource utilization education, informal education, Geography education, and Science education. Environmental education derives its power from these sources. However, the focus is on common relations between nature and social systems, humanity's association with nature, technology and preferences, and developmental learning that continues throughout human life (Roth, 1992, p.16-17). At this point, "environmental education is the process of developing attitudes, value decisions, knowledge and skills for environmental protection and demonstrating environmentally friendly behavior and seeing their results" (Erten, 2004). In other words, to inform all people in society about the environment, to raise awareness, to make positive and permanent behavioral changes and to ensure the active participation of individuals in solving problems (Özey, 2009, p. 24). Environmental education strives for economic, ecological, social and political awareness. In other words, environmental education is to educate generations who can act responsibly 
and lead environmental problems now and in the future by giving students problemsolving skills and personal responsibility (Roth,1968, p.4). The aim of environmental education is to create an individual and society that instill an individual responsibility that prevents the emergence of environmental problems and treats the deteriorating environment, develops environmental sensitivity, questions all patterns to live in a better environment (Özey, 2009, p. 24). One of the important aims of environmental education is to educate environmentally literate individuals who treat the environment respectfully and responsibly (Hares, Eskonheimo, Myllyntaus, \& Luukkanen, 2006,). In order to understand how environmental literate individuals should behave, it would be useful to first examine the concept of environmental literacy.

The concept of being literate appears in various forms and content in everyday language. In general, the concept of being literate means being one who has studied, who has read and write, while literacy also means a state of being literate (Yılmaz, 1989, p. 48). At the present time, the concept of literacy can be used in different meanings. One of these meanings is being well educated in different fields and having a wide knowledge of the field (Kışoğlu, Gürbüz, Sülün, Alaş \& Erkol, 2010, p. 777). At this point, one of the concepts used as literacy is environmental literacy. Environmental literacy is a personal learning process influenced by socio-economic, political, cultural, historical and ecological conditions (Hares et al., 2006, 129). Another definition is the capacity to perceive and interpret the healthy functioning of environmental systems, as well as to make appropriate decisions that will ensure the protection, restoration and development of these systems (Roth, 1992, p.17). In its most general sense, environmental literacy means understanding how human actions and decisions affect the quality of the environment by acting responsibly and effectively according to this understanding (Archie, 2003, p.7). Environmental literacy can be functionally divided into three levels: low (nominal), functional, and operational levels (Roth, 1992, p.17). A good environmental education is expected to make individuals actively environmentally literate (Karatekin \& Aksoy, 2012, p.1425). At this point it would be useful to look at the characteristics of environmentally literate individuals. These features include:

- An environmentally literate person should be able to notice environmental problems. In other words, they must understand the basic relationships between humans and their biological, geographical and chemical environment.

- Environmentally literate people can make the right decisions about protecting the environment and devote time and money to it. In other words, they are the ones who can ask questions to the appropriate government official at the right time, enlighten the people around them and mobilize people about environmental issues.

- Environmentally literate people have a sense of management and think about the quality of life; they also understand the resources of the world are limited. 
- An environmentally literate person knows that education is not limited only to schools and colleges. People's attitudes towards the environment form and continue to form in the family and early-years of life before starting school.

- People who are environmentally literate are aware that one of the basic rules of life is change.

- An environmentally literate person constantly questions the values in their culture surrounding new knowledge about natural resources and people (Roth, 1968, p. 6-8).

Environmental literacy skills include cognitive and affective skills, the ability to work in cooperation with others, develop communication skills, understand complex information, to analyze and apply such information to new situations, and the acquisition of higher-level skills to develop psychomotor capabilities (As cited by Karatekin \& Yılmaz, 2019, p. 35-36). One of the areas of learning that will enable attainment of environmental literacy skills is in Social Studies education because environmental literacy skills are included in the Social Studies curriculum (Ministry of National Education (MoNE), 2018, p. 9). One of those who will achievement this skill during educational periods are the Social Studies teachers. However, first of all, teachers must graduate by achievement this skill from undergraduate programs.

The current study aims to examine the environmental literacy levels of Social Studies teacher candidates and explore their views on this issue. Therefore, answers to the following questions were sought:

a. What are the environmental literacy levels of Social Studies teacher candidates?

b. Do the environmental literacy levels of Social Studies teacher candidates differ significantly by gender?

c. Do the environmental literacy levels of Social Studies teacher candidates differ significantly according to class level?

d. What are the Social Studies teacher candidates ' views about environmental literacy?

e. What are the views of Social Studies teacher candidates on their activities to improve their environmental literacy skills?

f. What are the views of Social Studies teacher candidates on the difficulties they face in attainment environmental literacy skills?

\section{Methodology}

\section{Model of Research}

In this study, an explanatory sequential design was used, which is a mixed research design. In this design, first quantitative data and then qualitative data are collected and analyzed. Qualitative research, which is the second level, is carried out by following the results of quantitative research, which is the first level (Delice, 2015, p.79). 
Akkaya Yllmaz, M. (2021). A study on environmental literacy levels of social studies teacher.....

\section{Working Group}

The study was conducted with candidate teachers studying Social Studies in a Faculty of Education at two state universities. Teacher candidates participating in the study were determined on a voluntary basis, and data were collected from participants in two stages.

Table 1

Demographics of Teacher Candidates Participating in The Environmental Literacy Survey

\begin{tabular}{lllll}
\hline \multirow{4}{*}{ Gender } & & $\mathbf{f}$ & $\mathbf{\%}$ \\
\cline { 2 - 4 } & Female & 105 & 69.1 \\
\cline { 2 - 4 } & Male & 47 & 30.9 \\
\cline { 2 - 4 } Grade level of Education & 1.Grade & 152 & 100 \\
\cline { 2 - 4 } & 2.Grade & 14 & 9.2 \\
\cline { 2 - 4 } & 3.Grade & 38 & 38.2 \\
\cline { 2 - 4 } & $4 . G r a d e$ & 46 & 22.4 \\
\cline { 2 - 4 } & Total & 152 & 10.3 \\
\hline
\end{tabular}

A total of 152 Social Studies teacher candidates participated in the environmental literacy survey. $69.1 \%$ of respondents $(f=105)$ were female teacher candidates, while $30.9 \%(\mathrm{f}=47)$ were male teacher candidates. $9.2 \%(\mathrm{f}=14)$ of the participants were first-grade teachers, $38.2 \%(\mathrm{f}=58$ ) were second-grade teachers, $22.4 \%$ ( $\mathrm{f}=$ 34 ) were third-grade teachers, and $30.3 \%(f=46)$ were fourth-grade teachers.

Table 2

Demographics of Teacher Candidates Participating in the Semi-Structured Interview Form

\begin{tabular}{llll}
\hline \multirow{4}{*}{ Gender } & & $\mathbf{f}$ & $\mathbf{\%}$ \\
\cline { 2 - 4 } & Female & 9 & 75 \\
\cline { 2 - 4 } & Male & 3 & 25 \\
\cline { 2 - 4 } Grade level of Education & Total & 12 & 100 \\
\cline { 2 - 4 } & 1.Grade & 3 & 25 \\
\cline { 2 - 4 } & 2.Grade & 3 & 25 \\
\cline { 2 - 4 } & 4.Grade & 3 & 25 \\
\cline { 2 - 4 } & Total & 12 & 100 \\
\hline
\end{tabular}

A total of 12 Social Studies teacher candidates participated in the semi-structured interview form in the study. $75 \%$ of respondents $(f=9)$ were female teacher candidates, while $25 \%(\mathrm{f}=3$ ) were male teacher candidates. In addition, a total of 12 teacher candidates, 3 teacher candidates from each level, participated in the interview.

\section{Data Collection}

Quantitative data of the study was collected through the "environmental literacy survey", developed by Karatekin (2011). Knowledge and skill tests were adapted to the dimensions of attitude and behavior while qualitative data were collected through the semi-structured interview form developed by the researcher. 
Environmental literacy consists of five areas. The researchers included a portion of the survey's affective trends scale, environmental behavior scale, and environmental knowledge test questions published by the Wisconsin Center for Environmental Education in "Environmental Education in Wisconsin: Are we walking the talk? it was used with the permission of the institution mentioned in the "High School Environmental Survey", which it used in its report. Again, used some of the questions of the environmental knowledge test with permission from Timur's (2011) doctoral dissertation, while he also created some of the questions himself. For the cognitive skills test, the researcher created a text about genetically modified organisms and asked the teacher candidates to line up the scientific research steps given in mixed form using this text.

For the external validity of the scale, the researcher received opinions from 10 experts working in the fields of Science Education, Biology Education, Geography Education, Social Studies Education, Educational Sciences and measurement and evaluation and made the necessary corrections. Gazi Faculty of Education Social Studies Teaching for Grade 4 conducted a preliminary application with 10 students studying in class, and thus the survey was prepared for a pilot application. The pilot application is Grade 4 of various universities. It conducted it with 157 Social Studies teacher candidates.

Karatekin (2011) determined the Kr-20 reliability factor of the Environmental Information test as 0.71 , the Cronbach-Alpha multiple of the affective trends scale for the environment as 0.78 , and the Cronbach-Alpha reliability multiple of the environmental behavior scale as 852. In the cognitive skills section, the researcher created a text from a conversation in a panel and asked the participants to place the steps of scientific research in order, which were given in mixed form, using this text. In this study, only two questions contained in the personal information form were used.

In the qualitative part of the study, the semi-structured interview form developed by the researcher was used. A number of stages have been followed in the preparation of this form. First, the literature was in detail and then an item pool was created. Then the researcher made some qualifiers from the item pool. A fivequestion form created as a result of this elimination was submitted to the opinion of three separate social studies and a Turkish expert, and the necessary corrections were made. A pilot application was then made with three Social Studies teacher candidates and the form was given a final version of three questions.

\section{Data Analysis}

Karatekin (2011) used the model developed by McBeth, Hungerford, Marcinkowski, Volk and Meyers (2008) when determining the environmental literacy levels of Social Studies teacher candidates. Accordingly, the standardized maximum score that teacher candidates will receive from all scales is determined as 60. Multiplier values were then determined to calculate the maximum scores that can be obtained from each scale according to this standardized score (Table 3). 
Akkaya Yllmaz, M. (2021). A study on environmental literacy levels of social studies teacher.....

According to this model, environmental literacy levels were evaluated in three categories: Low, Medium and High, and information about the environmental literacy levels of Social Studies teacher candidates are included in Table 4.

Table 3

Multiplier Values Used to Determine the Environmental Literacy Levels of Social Studies Teacher Candidates and The Maximum Scores That Can Be Obtained from Each Scale

\begin{tabular}{lcccc}
\hline $\begin{array}{l}\text { Components of } \\
\text { Environmental } \\
\text { Literacy }\end{array}$ & $\begin{array}{l}\text { Number of } \\
\text { questions }\end{array}$ & Points range & Multiplier & Max Points \\
\hline Knowledge & 21 & $0-21$ & 2,857 & 60 \\
\hline Affective & 27 & $27-135$ & 0,444 & 60 \\
\hline Behavioral & 19 & $19-95$ & 0,631 & 60 \\
\hline Cognitive skills & 7 & $0-7$ & 8,571 & 60 \\
\hline Total & 73 & $46-258$ & & 240 \\
\hline
\end{tabular}

(Karatekin, 2011, p.162)

In Table 3, the multiplier value of the environmental knowledge test was "2,857"; the multiplier value of the affective tendencies scale was "0.444"; the multiplier value of the Behavior Scale was "0.631"; and the multiplier value of the cognitive skills test was 8.571 . Therefore, the highest score that can be obtained from each scale was "60". Based on the standardized score, the highest environmental literacy score was set at 240 , and the lowest environmental literacy score was set at 24 . In addition, the environmental literacy level has been determined as low-medium and high, and accordingly it shows a low level of environmental literacy between 24 96 points and a high level of environmental literacy between 97 - 168 and an average of 169 - 240 points. In the study, such criteria were used.

The normality of the distribution should be examined when analyzing the data. Many parameters are used when examining the normality of the distribution. One of them is the Kolmogorov-Simirnov (K-S) and Shapiro-Wilks tests (Büyüköztürk, 2020, p.43). In the analysis of the study, parametric tests were performed on data showing distribution normality and nonparametric tests were performed on data showing distribution normality. In addition, the equality of variance was also looked at using the Levene test.

In the study, percentage, frequency, independent groups T test, Mann-Whitney$\mathrm{u}$, single factor variance analysis (ANOVA) and Kruskal-Wallis tests were used to show environmental literacy subcomponents and environmental literacy levels of teacher candidates. In the analysis of the qualitative data of the study, percentage and frequency were used.

To ensure the reliability of qualitative data of research, Miles and Huberman's (1994, p.64) developed reliability formula was used. The data set was encoded independently of each other by a researcher and an expert in Social Studies education. Accordingly, the consistency ratio between encodings was determined as $90 \%$. 


\section{Findings}

In this part of the research, quantitative and qualitative data on environmental literacy will be analyzed.

Table 4

Environmental Literacy Levels of Social Studies Teacher Candidates

\begin{tabular}{|c|c|c|c|c|c|c|}
\hline $\begin{array}{l}\text { Sub-Dimensions of } \\
\text { Environmental } \\
\text { Literacy } \\
\end{array}$ & & Low & Medium & High & $\overline{\mathrm{X}}$ & $S$ \\
\hline \multirow{3}{*}{ Knowledge test } & Rank & $0-20$ & $21-40$ & $41-60$ & \multirow{3}{*}{31,41} & \multirow{3}{*}{10,30} \\
\hline & $f$ & 28 & 101 & 23 & & \\
\hline & $\%$ & 18,42 & 66,44 & 15,13 & & \\
\hline \multirow{3}{*}{$\begin{array}{l}\text { Affective tendencies } \\
\text { scale }\end{array}$} & Rank & $12-28$ & $29-44$ & $45-60$ & \multirow{3}{*}{46,51} & \multirow{3}{*}{5,43} \\
\hline & $f$ & - & 63 & 89 & & \\
\hline & $\%$ & - & 41,44 & 58,55 & & \\
\hline & Rank & $12-28$ & $29-44$ & $45-60$ & \multirow{3}{*}{39,05} & \multirow{3}{*}{8,19} \\
\hline Environmental & $f$ & 14 & 103 & 35 & & \\
\hline Behavior Scale & $\%$ & 9,21 & 67,76 & 23,02 & & \\
\hline \multirow{3}{*}{ Cognitive Skills Test } & Rank & $0-20$ & $21-40$ & $41-60$ & \multirow{3}{*}{13,31} & \multirow{3}{*}{11,54} \\
\hline & $f$ & 124 & 21 & 7 & & \\
\hline & $\%$ & 81,57 & 13,81 & 4,60 & & \\
\hline \multirow{4}{*}{$\begin{array}{l}\text { Environmental } \\
\text { Literacy Total }\end{array}$} & $\underline{\text { Rank }}$ & $24-96$ & 97- & $169-240$ & \multirow{4}{*}{130,29} & \multirow{4}{*}{23,24} \\
\hline & & & 168 & & & \\
\hline & $\bar{f}$ & 9 & 132 & 11 & & \\
\hline & $\%$ & 5,91 & 86,84 & 7,23 & & \\
\hline
\end{tabular}

As can be seen in Table 4, low level is $0-20$, medium level is $21-40$, and high level is $41-60$ as determined in the knowledge test. According to this, $18.42 \%$ (28) of the teacher candidates are in the low-level range, whereas $66.44 \%$ (101) are in the middle level range, and $15.13 \%$ (23) are in the high level range. The average score of teacher candidates from the knowledge test was determined to be $\bar{X}$ $=31.41$. Accordingly, it is seen that the knowledge level of the teacher candidates is at a moderate level.

On the affective tendencies scale, it was determined as a low level between 12 28, a medium level between $29-44$ and a high level between $45-60$. According to this, none of the teacher candidates are in the low-level range, whereas $41.44 \%$ (63) are in the middle level range, and 58.55\% (89) are in the high-level range. The average score of teacher candidates on the affective tendencies scale was determined to be $\bar{X}=46.51$. Accordingly, it seems that the cognitive levels of teacher candidates are at a high level, but close to the lower limit of the high level.

On the behavior scale, it was determined as a low level between $12-28$, a middle level between 29 - 44 and a high level between $45-60$. According to this, $9.21 \%$ (14) of the teacher candidates are in the low-level range, whereas $67.76 \%$ (103) are in the middle level range, and $23.02 \%$ (35) are in the high level range. The average score of teacher candidates on the Behavior Scale was determined to be $\bar{X}=39.05$. Accordingly, it is observed that the behavior of the teacher candidates is moderate. 
Akkaya Yllmaz, M. (2021). A study on environmental literacy levels of social studies teacher......

In the cognitive skills test, low levels between $0-20$, intermediate levels between $21-40$ and high levels between 41 - 60 were determined. According to this, $81.57 \%$ (124) of the teacher candidates are in the low-level range, $13.81 \%$ (21) are in the middle-level range, and 4.60\% (7) are in the high-level range. The average score of teacher candidates from the cognitive skills test was $\overline{\mathrm{X}}=13.31$. Accordingly, it is observed that the cognitive skills of the teacher candidates are at a low level.

The knowledge test, Affective tendencies scale, Behavior Scale, and cognitive skills test were used to determine the environmental literacy levels of Social Studies teacher candidates. According to the standardized score, it was determined as low level 24 - 96, low level 97 - 168 and high level 169 - 240. According to this, 5.91\% (9) of the teacher candidates are in the low-level range, whereas $86.84 \%$ (132) are in the middle-level range, and $7.23 \%$ (11) are in the high-level range. The average score of teacher candidates from four different components of environmental literacy was determined to be $\overline{\mathrm{X}}=130.29$. Accordingly, it can be stated that the environmental literacy levels of teacher candidates are moderate.

Table 5.1

$T$ - Test Results for Independent Samples of the Behavior Scale from Components That Make Up the Environmental Literacy of the Gender Variable

\begin{tabular}{|l|l|l|l|l|l|l|l|}
\hline & Gender & $\mathbf{n}$ & $\overline{\mathrm{X}}$ & $\mathbf{S}$ & sd & t & P \\
\hline $\begin{array}{l}\text { Behavior } \\
\text { Scale }\end{array}$ & Female & 105 & 38.31 & 8.276 & \multirow{2}{*}{150} & 1,672 & \multirow{2}{*}{097} \\
\cline { 2 - 5 } & Male & 47 & 40.70 & 7.816 & & & \\
\hline
\end{tabular}

According to the T test results in Table 5.1, the Behavior Scale scores of teacher candidates did not differ significantly in terms of gender $[t(150)=1,672 ; p>05]$. Accordingly, it can be said that the behavior scores of participants are similar in terms of gender.

Table 5.2

Mann Whitney-U Test Results for Gender Differences in Information, Affective, Cognitive, And Total Scores

\begin{tabular}{|c|c|c|c|c|c|c|}
\hline & Gender & & & & $\mathbf{U}$ & $\mathbf{P}$ \\
\hline & & $\mathbf{N}$ & Rank Average & Rank Total & & \\
\hline Knowledge test & Female & 105 & 74.93 & 7867.50 & 2302.500 & .509 \\
\hline & $\overline{\text { Male }}$ & 47 & 80.01 & 3760.50 & & \\
\hline$\overline{\text { Affective }}$ & Female & 105 & 76.63 & 8046.00 & 2454.000 & .957 \\
\hline & $\overline{\text { Male }}$ & 47 & 76.21 & 3582.00 & & \\
\hline Cognitive Test & Female & 105 & 76.74 & 8057.50 & 2442.500 & .917 \\
\hline & Male & 47 & 75.97 & 3570.50 & & \\
\hline Environmental & Female & 105 & 74.76 & 7850.00 & 2285.000 & .467 \\
\hline & Male & 47 & 80.38 & 3778.00 & & \\
\hline
\end{tabular}


Testing the knowledge of teacher candidates by the affective tendencies scale, cognitive testing, and environmental literacy by gender did not show a significant difference in total scores $(U=2302.500, p>, 05),(U=2454.000, p>, 05),(U=$ $2442.500, p>05)$ and $(U=2285.000, p>05)$. Accordingly, it can be said that the participants ' knowledge scores, affective scores, cognitive scores and environmental literacy scores are similar in terms of gender.

Table 6.1

Affective and Behavioral Scores from Environmental Literacy Subcomponents of Teacher Candidates and ANOVA Results On Class Level

\begin{tabular}{|l|l|l|l|l|l|l|l|}
\hline $\begin{array}{l}\text { Components of } \\
\text { environmental } \\
\text { literacy }\end{array}$ & $\begin{array}{l}\text { Grade } \\
\text { Level }\end{array}$ & $\mathbf{N}$ & $\bar{X}$ & S & Sd & F & P \\
\hline \multirow{2}{*}{ Affective } & 1. Grade & 14 & 47,14 & 4.348 & & & \\
Tendencies Scale & 2. Grade & 58 & 45,57 & 5.500 & 3 & & \\
& 3. Grade & 34 & 46,50 & 6.175 & 148 & 1,182 &, 319 \\
& 4. Grade & 46 & 47,52 & 4.979 & 151 & & \\
& Total & 152 & 46,51 & 5.427 & & & \\
\hline Behavior Scale & 1. Grade & 14 & 39,29 & 7.819 & 3 &, 067 &, 977 \\
& 2. Grade & 58 & 39,03 & 8.305 & 148 & & \\
& 3. Grade & 34 & 38,56 & 9.554 & 151 & & \\
& 4. Grade & 46 & 39,37 & 7.249 & & & \\
Total & 152 & 39,05 & 8.186 & & & \\
\hline
\end{tabular}

Affective tendencies scale scores and Behavior Scale scores of teacher candidates did not differ significantly from the class variable $[F(3-148)=1,182 ; p>, 05],[F(3-$ $148)=, 067 ; p>, 05]$. This finding can be interpreted as the Affective tendencies scale and Behavior Scale scores of participants are similar in terms of class level.

Table 6.2

Kruskal Wallis Results On Grade Level with Knowledge Test, Cognitive Test and Environmental Literacy Total Scores from Environmental Literacy Sub-Dimensions of Teacher Candidates

\begin{tabular}{|c|c|c|c|c|c|c|}
\hline & Grade & $\mathbf{N}$ & $\begin{array}{l}\text { Rank } \\
\text { Average }\end{array}$ & sd & $\mathbf{X}^{2}$ & $\mathbf{P}$ \\
\hline \multirow{5}{*}{$\begin{array}{l}\text { Knowledge } \\
\text { Test }\end{array}$} & 1.Grade & 14 & 78.39 & \multirow[t]{5}{*}{3} & \multirow[t]{5}{*}{1,531} & \multirow[t]{2}{*}{675} \\
\hline & 2.Grade & 58 & 70.99 & & & \\
\hline & 3.Grade & 34 & 81.15 & & & \\
\hline & 4.Grade & 46 & 79.43 & & & \\
\hline & Total & 152 & & & & \\
\hline \multirow{5}{*}{ Cognitive Test } & 1.Grade & 14 & 74.04 & \multirow[t]{5}{*}{3} & \multirow[t]{5}{*}{4.956} & \multirow[t]{5}{*}{ 175 } \\
\hline & 2.Grade & 58 & 67.42 & & & \\
\hline & 3.Grade & 34 & 83.44 & & & \\
\hline & 4.Grade & 46 & 83.57 & & & \\
\hline & Total & 152 & & & & \\
\hline \multirow{5}{*}{$\begin{array}{l}\text { Environmental } \\
\text { Literacy Total }\end{array}$} & 1.Grade & 14 & 81.11 & \multirow[t]{5}{*}{3} & \multirow[t]{5}{*}{3.876} & \multirow[t]{5}{*}{,275 } \\
\hline & 2.Grade & 58 & 67.62 & & & \\
\hline & 3.Grade & 34 & 80.82 & & & \\
\hline & 4.Grade & 46 & 83.10 & & & \\
\hline & Total & 152 & & & & \\
\hline
\end{tabular}


The participants ' knowledge test, cognitive tendencies scale, and environmental literacy total score did not differ significantly by class level $(X 2=1,531, p>, 05)$, $(X 2 b=b 4.956, p>, 05),(X 2=3.876, p>, 05)$. Accordingly, it can be said that participants ' knowledge test scores, cognitive test scores, and environmental literacy scores are similar according to class level.

Table 7

Social Studies Teacher Candidates ' Views About What Environmental Literacy Is

\begin{tabular}{ll}
\hline Categories & f \\
\hline Heritage & 5 \\
\hline Knowledgeable & 4 \\
\hline Sensitivity & 2 \\
\hline Effect & 1 \\
\hline Total & 12 \\
\hline
\end{tabular}

In the interviews conducted, it is seen that teacher candidates rate heritage as the most identified component of environmental literacy $(\mathrm{f}=5)$. Teacher candidates emphasized the point of transferring the environment to future generations. Some of the answers are:

Participant 5: "We, as humanity, are involved in a particular ecosystem. We are also responsible for our environment and future generations. I think this is defined as the transfer of responsibility to students to the opposite party in the form of information. It is the efficient use of the resources of our environment and the transfer of them to future generations".

Participant 7: "Teacher, I think we all live in an ecosystem. I can say that this is a discipline developed to develop this ecosystem that we are a part of and pass it on to future generations."

Participant 9: "So, my teacher, I define it as follows: the values around us can be historical, social, cultural, they are protected and passed on to future generations by protection. It is to fulfill all the responsibilities we can for a sustainable life and thus leave the environment to future generations in a healthy way."

Teacher candidates expressed an opinion in the category of being second most knowledgeable $(\mathrm{f}=4)$. Teacher candidates emphasized the point of having a wide knowledge of the environment. Some of the answers are as follows.

Participant 1: "environmental literacy is more like this, teacher, to know the environment, to promote it, to raise awareness of people, I understand it more like this. It means knowing the environment in all its aspects".

Participant 6: "My Teacher is able to master and interpret events about the environment in all ways".

Participant 8: "I can think of a definition of a person being aware of everything he sees around him. In fact, it is to become aware of events related to the environment". 
Another category created according to the responses of teacher candidates is the sensitivity category. Teacher candidates stated that affective sensitivity to the environment should be shown. The answers are as follows:

Participant 2: "It awakens me to be conscious of the environment. It evokes more sensitivity, more common sense. We have to take on a number of tasks ourselves individually. For example, we should not waste water in our house. I saw a documentary about 20 liters, and it really impressed me. Every time I flush like this, I think about it. So we have to be more sensitive to nature".

Participant 11: "it is the level of sensitivity to the environment. It must be aware that he should not throw trash around. You know, it's not a punishment or a sanction, but it must have internalized it. It should be sensitive. Because he should also know that paper, plastic, has not melted in the soil for centuries, and therefore the soil has become inefficient, and I should also think ahead."

According to the responses of the teacher candidates, a participant defines environmental literacy as interaction. The answer for this is as follows:

Participant 3: "I think it is the ability to understand and interpret the surrounding systems, in short, to increase the interaction between nature and man".

Given the responses of teacher candidates, it can be said that they do not know exactly what environmental literacy is. However, a significant number of teacher candidates have expressed an opinion about the categories of heritage and knowledge. When the responses to these categories are examined, it seems that teacher candidates express the concepts of knowing, and knowing and being responsible for the environment, which are within the scope of environmental literacy. In addition, when examining the responses of teacher candidates, it can be said that environmental literacy has expressions related to the information dimension, affective dimension, and behavioral dimension. In addition, although it is not easy to determine which level of environmental literacy individuals are based on a question, when studying the definitions of students, it can be said that they are not at the level of operational literacy.

Table 8

Social Studies Teacher Candidates ' Views About What They Do to Improve Environmental Literacy Skills

\begin{tabular}{ll}
\hline Categories & f \\
\hline Learn knowledge & 7 \\
\hline Watch the documentary film & 5 \\
\hline Project etc. participating in activities & 3 \\
\hline non-governmental organizations & 3 \\
\hline Nothing to do & 2 \\
\hline Taking advantage of the lessons & 1 \\
\hline Symposium etc. participating in activities & 1 \\
\hline
\end{tabular}

In this question, teacher candidates mentioned their activities to improve themselves on environmental literacy, and the majority stated that they had carried out more than one activity at this point. For this reason, the answers of the teacher candidates were evaluated in more than one category. 
It was found that participants mostly expressed opinions in the category of learning information $(\mathrm{f}=7)$. Participants stated that they tried to increase their knowledge of environmental literacy by reading articles, books, magazines, as well as watching television programs. Some of the answers in this category are:

Participant 4: "I am reading various research, articles, research articles on this subject..."

Participant 6:" ...I am studying readings, articles, media news..."

Participant 9: "Teacher, I am trying to be as sensitive to the environment as I can. I then turn to articles, books about it..."

Participant 12: "I, for myself, have been very interested in these topics since middle school. I like to read articles about it or something...."

Participants mentioned that they watched environmental documentaries as the second most $(\mathrm{f}=5)$. In this way, they try to improve themselves. Some of the answers in the category are:

Participant 3: “... I watch environmental documentaries...”

Participant 4: “...I watch documentaries...".

Participant 11: "... I care about environmental pollution. I watch information-size documentaries film. I'm looking at the effects of our misbehavior on other animal species and human species. For example, there are people in Africa who have water problems, or because of glacial melting at the poles, we can see that penguins drown because polar bears have to swim for miles and can no longer swim."

Participant 12: "...and I usually watch a documentary film about it on TV or something like that. I'm very interested."

Three of the teacher candidates mentioned that they are trying to improve environmental literacy skills by participating in activities and projects The answers on this topic are:

Participant 2: "... I participated in the sister school project last year we bought saplings. I'm more interested in things like planting trees. I'm trying to participate in environmental projects."

Participant 3:" ... I try to participate in a lot of activities, such as planting trees ... I participate in various small or large projects related to the environment. For example, to recycling".

Participant 11: "teacher, we have done several projects before. You know, for example, we talked about recycling waste in classrooms, and we talked about it in elementary and high school classrooms. Before, we put such small little boxes because I studied child development. I thought we did what we had to throw where. So we tried to instill consciousness in children. Then there was this blue cover project. I also have brothers I know from a rehabilitation center, I helped him a lot because of the obstacle situation, we collected a lot of covers, and now I myself use waste material at home, if I drink mineral water, I collect it and put it next to the trash, so that they can take it to recycling..." 
Three of the candidate teachers stated that they are members of nongovernmental organizations or that they operate within this framework. The answers in this category are:

Participant 3: "...I am a member of NGOs, I develop myself through these activities..."

Participant 6: "most simply, I am the deputy provincial president of an NGO. we were at the site of the nearest Izmir earthquake. When you work in the field, you get a lot of different experiences. I became a member of environmental NGOs..."

Participant 10: I follow the work of my teacher Greenpeace Team. I'm learning what's going on around here. I know and learn everything that harms nature. If necessary, there are even autographs. I'm signing them through Change. Because I really want to leave this world in which we live well for future generations... I learn about the activities of non-governmental organizations...".

Two of the participants mentioned that they did nothing to improve themselves on environmental literacy. The answers on this topic are:

Participant 1:" I'm not doing anything".

Participant 5:" There's nothing I'm doing right now to improve myself".

One of the teacher candidates mentioned that they benefit from lessons, while another teacher candidate mentioned that they benefit from scientific activities such as a panel, symposium. The answers in these categories are:

Participant 7: “... I try to improve my skill by learning knowledge from lessons".

Participant 9: “... then I take care to attend the panels, symposia prepared about it".

Being an environmentally literate individual requires first of all to be able to get to know the environment well and to predict what impact the decisions we make will have on our environment. At this point, it can be said that participants endeavor to become an environmentally literate individual because a significant part of teacher candidates' education is to learn about the environment books, magazines, articles, documentaries, lectures, etc., thus they are trying to improve themselves in such ways.

Table 9

Social Studies Teacher Candidates 'Views About The Difficulties They Face In Acquiring Environmental Literacy Skills

\begin{tabular}{ll}
\hline Categories & f \\
\hline Education & 9 \\
\hline Family & 6 \\
\hline Society & 5 \\
\hline Politic of states & 1 \\
\hline I didn't face any difficulties & 1 \\
\hline
\end{tabular}


In this question, teacher candidates mentioned the difficulties they faced in gaining environmental literacy, and the majority stated that they faced more than one difficulty at this point. For this reason, the answers of the teacher candidates were evaluated in more than one category.

Teacher candidates have mentioned they have difficulty in education at the point of gaining this skill the most. Some of them mentioned that the lessons on this subject were insufficient, some of them were insufficient content, even if they were lessons, and some of them mentioned that teachers were negative role models. Some of the answers in this category are:

Participant 1: "we didn't get enough of classes in college or elementary or high school. Even if there are lessons, I don't find the content enough. "

Participant 2:" ... the lack of Education did not give us enough of this consciousness. We had to win ourselves".

Participant 3: "... teachers weren't doing what they told us. They weren't role models. They showed us trash collection as punishment. False teacher teachings...".

Participant 8: "since primary school, our education has been inadequate. I think it's a very insufficient concept in primary schools and secondary schools. I think that's our biggest challenge....when we were in elementary school, they made us collect trash in the garden. The teacher didn't collect it, and I passed it. Between breaks, teachers were smoking, throwing the cigarette butts on the floor, for example. For example, he was not a role model in this regard...".

Participant 9: "... I don't believe that there is much emphasis on this issue in the schools I also study. I haven't seen much about it in my high school, middle school, elementary life. There were classes at school. But it wasn't really shown to us. I'll just teach you a lesson, you know, you came to school, I'll teach you a lesson, I'll tell you a lesson. So I couldn't improve much, to be honest. Although there were lessons or subjects, their content was not satisfactory enough".

Participant 12: "...when we learned in lessons, I think it was very incomplete, we were just going over it. That's the last thing I've always said. If we had learned about this first, maybe we would have been better environmental literate in the lessons if we had given more weight to it. We've seen it in classes, but it's not detailed enough. I don't know if it's because they weren't asked or because the teachers didn't care, but I don't remember the teachers ever stopping too much. Society is indifferent about this in a general sense. After a while, we also give up..."

Teacher candidates mentioned they experienced difficulties caused by their families most $(\mathrm{f}=6)$. Some of them said that their families are not very knowledgeable or sensitive about this, some of them are not very supportive of it. Some of the answers in this category are:

Participant 1: "...our family also did not raise enough awareness about this issue. I mean, if we went to the family now, no one taught the family. A deficiency from the past, my teacher".

Participant 3: "education begins in the family. I don't think our family can teach a lot of things at this point. They weren't doing what they told us..."

Participant 7:".... Education begins in the family, so to a certain point, my family is responsible... my family is also responsible. I'd like my family to be a little more aware of it...".

Participant 12: "my teacher, first of all, I don't know everything, it doesn't change anything. For 
this, I cannot develop a complete environmental literacy skill unless even my family is whole with me. For example, we spend too much water when I mention it to my family, most of them disagree with me. Our lack of unity prevents it. My parents aren't sensitive enough about it..."

Some of the teacher candidates also mentioned that society has a prohibitive effect on attainment environmental literacy. Some of the answers on this topic include:

Participant 4: "I definitely mean my environment. I think I think that because of the lack of education and selfishness of people around me. My environment has prevented me from being conscious enough. For example, when I was out with my friends, I saw Butts that people threw on the floor. I think hunting, called sports, is a massacre. The insensitivity of my environment to the environment also negatively affected my sensitivity.

Participant 7: "... people's indiscretion made it difficult for me to learn this skill. I see that there are people who have these days in their logic. Let me live, and whatever happens after me has logic."

Participant 8: "... people around us also throw trash and many things on the floor. And there are no people around us who will be role models. And that was missing from me."

One participant mentioned that the policies of the states were insufficient, while another participant noted that he did not experience any difficulties. The answers in these categories are:

Participant 7: "... in addition, government policies are very effective in this regard. If we don't support domestic seed and support hybrid... or a lot of heads of state meet every year and decisions are made to let us do this, but I don't think any of the decisions are implemented in any country. I think government policies are also responsible...states are not very sensitive to the environment.

Participant 11: "I try to be sensitive as much as I can. Honestly, I don't think I've learned... And I had no trouble learning. My primary school teachers were very, very good. We used to do ... we'd have a day on a weekday. The school belonged to us, we collected trash in his garden. Or in gym class, we'd warm up, walk, run, and pick up our trash together. Because of him, I had a good education and a good childhood, so I didn't have a lot of trouble with it. I'm an environmental literate individual. I have not encountered any difficulty in attainment this skill.

Teacher candidates have mentioned they have a number of difficulties in acquiring environmental literacy skills. Based on this, it can be inferred that students do not see themselves as fully environmentally literate individuals. A significant number of students complained about the lack of education in particular. Some have mentioned that the lessons are inadequate, some have mentioned the lack of content, and some have mentioned that teachers are negative role models. They also said that there are negative effects on family and society. At this point, considering that family and society can also be changed through education, it can be stated that the inclusion of environmental issues in our education from primary school to higher education will make a significant contribution.

\section{Result and Discussion}

According to the findings obtained in the study, Social Studies teacher candidates had moderate knowledge levels, high affective tendencies, moderate behavior levels, low cognitive skills, and moderate environmental literacy levels. 
In order to improve these moderate environmental literacy skills, teacher candidates conduct readings from sources such as articles, books, magazines, watch documentaries, projects and so on. The teacher candidates also mentioned that they participated in activities, were members of NGOs or participated in their activities, benefited from lectures, and participated in symposium-like activities. Only two prospective teachers said they did nothing to improve their skills.

In this study, it can be mentioned that teacher candidates are working to improve their moderate environmental literacy levels. Results from environmental literacy and dimensions in this study are similar to results from other study by Karatekin and Aksoy (2012). Studies conducted by Daudi (2000); Kışoğlu (2009); Altınöz (2010); Gürbüz et al. (2011); Timur (2011); Bilim (2012); Özyürek et al. (2019) also supports the result of environmental literacy levels shown in this study. Şenyuva and Bodur (2016) concluded in their study that the environmental literacy levels of university students were moderate. Fettahlığlu (2018) concluded that $67.5 \%$ of teacher candidates had moderate levels of environmental literacy, while $50 \%$ had positive attitudes towards the environment. Despite these results, a study by Koç, Çorapçıigil and Doğru (2018) concluded that 86.61\% of Senior Science teacher candidates had very high environmental literacy levels. Özyürek et al. (2019) said the result about attitudes supports the result of Affective trends in this study. Again, in this study, the knowledge levels of Social Studies teacher candidates were determined as moderate, while Özyürek et al. (2019) found that the level of knowledge of teacher candidates was poor.

Another result from the survey data is that there was no significant difference between participants ' environmental literacy components and environmental literacy levels by gender and class level. In this study, it can be said that the level of environmental literacy of participants in terms of gender and class level is similar. As a matter of fact, there was no significant difference in the answers given in terms of gender or class level in the interviews. In their study, Koç and Karatekin (2013) found that environmental literacy levels of Geography teacher candidates did not differ according to gender and class variables. In their study, Şahin, Ünlü and Ünlü (2016) found no significant differences between the dimensions of the environmental literacy scale relative to the class level variable of Social Studies teacher candidates. Koç, Çorapçıil and Doğru (2018) concluded that the environmental literacy levels of Senior Science teacher candidates were not differentiated by gender. The finding on gender in the studies of Artun, Uzunöz and Akbaş (2013) parallels this study. Results from a study by Özyürek et al. (2019) does not support this study, while the results they obtained in the gender-related attitude sub-dimension do support this study, while the results they obtained in the genderrelated information sub-dimension support this study. Owens (2000) noted in his study that there was no difference in the environmental literacy levels of secondary school teachers in terms of gender. In his study, Kışoğlu (2009) found that there was no difference between the levels of environmental literacy in terms of the gender of the students prior to implementation.

One of the interview questions in the study investigated how participants defined environmental literacy. A large number of participants emphasized that the environment is a legacy that will be passed on to future generations. Again, a 
significant number of participants evaluated environmental literacy as having a wide knowledge of the environment. Although the affective tendency scores of the participants were high, two participants identified environmental literacy as sensitivity. One participant described environmental literacy as increasing the interaction between nature and man.

In another interview question, participants were asked about the difficulties they faced in acquiring environmental literacy skills. As a matter of fact, the environmental literacy levels of teacher candidates were found to be moderate. This, in turn, suggests that the teacher candidates have a number of shortcomings. A significant number of teacher candidates emphasized the lack of education in this regard. Some of the teacher candidates mentioned that the content of the courses on this subject was insufficient, while some of the teacher candidates mentioned that they did not see the courses on this subject. Some teacher candidates, on the other hand, have mentioned that teachers are a negative example. At this point, participants in the study of Kocalar and Balcı (2013) expressed an opinion on the provision of a course in environmental education and knowledge in schools. In his study Uyanık (2016) concluded that teacher candidates who took an environmental education course had higher knowledge and attitudes than non-teacher candidates.

Based on this, it can be said that in order to eliminate this difficulty faced by teacher candidates, it will be useful to teach courses related to the environment, at least in a license. Indeed, the study by Balkan, Kıyıcı, Atabek Yiğit and Darçın (2014) was closely associated with environmental education, and suggested that nature education was necessary to raise awareness amongst teacher candidates and concluded that the environment contributed to the development of their consciousness. Science teacher candidates in the study by Koç, Çorapçıgil and Doğru (2018) mentioned that undergraduate courses in educational life have a positive impact on environmental literacy. Based on this, it can be mentioned that education is important for environmental literacy. In other words, it can be said that a good environmental education increases students ' competence in this regard. Some of the teacher candidates mentioned that families have a negative impact on environmental literacy. Some complained that their families were not very knowledgeable or sensitive about it, others complained that they were not very supportive of it. Roth (1968) also mentioned that family is important at the point of environmental literacy. The Science teacher candidates in the study of Koç, Çorapçıil and Doğru (2018) mentioned that family behavior has a positive effect on environmental literacy.

A number of teacher candidates also mentioned that society has negative effects on this issue. Some have complained that people are uneducated, selfish, reckless, while others have talked about the negative impact of people throwing trash into the environment. One participant mentioned that it was a difficulty for state policies to be inadequate in this regard, while one participant mentioned that they did not face any difficulties. From the responses given, it can be said that participants in general lack environmental literacy. Indeed, they have mentioned that they have experienced difficulties. It can also be said that students did not fully attainment this skill by looking at the environmental literacy survey they answered. 


\section{Suggestions}

Although there has been intensive work in Science Education about environmental literacy, interest in this issue has increased in Social Studies education in recent years. In most studies, participants' environmental literacy levels were moderate.

In this study, it can be said that the participants in general are not functional environmentally literate individuals. Based on this, it can also be noted that environmental literacy skills are not fully acquired. As a matter of fact, this applies to the work done. It is observed that teacher candidates have difficulties in attaining environmental literacy skills, and this is most often caused by insufficient education, and then they also have a number of negative effects on the family and society.

It can be said that the most important proposal that can be brought in this study is the need to pay attention to the issue of the environment in education. Because as a result of the education of the family and society, it can be said that environmental conscious individuals will be formed.

\section{References}

Akıllı, M. ve Genç, M. (2015). Examination of middle school students' sub-dimensions of environmental literacy in terms of various variables. Sakarya University Journal of Education, 5(2), 81-97.

Archie, M. L. (2003). Advancing Education through Environmental Literacy. Alexandria, VA: The Harbinger Institute, Association for Supervision and Curriculum Development.

Artun, H., Uzunöz, A. ve Akbaș, Y. (2013). The evaluation of the factors affecting the levels of environmental literacy of social science prospective teachers. Pamukkale University Journal of Education, 34, 1-14.

Altınöz, N. (2010). Environmental literacy levels of prospective science teachers, (Unpublished master's thesis). Sakarya Üniversitesi Fen Bilimleri Enstitüsü, Sakarya.

Balkan Kıyıcl, F., Atabek Yiğit, E., ve Darçın, E. S. (2014). Investigation of pre-service teacher's opinion and environmental literacy level change with nature education. Trakya University Journal of Education, 4(1), 17-27.

Bilim, İ. (2012). Sustainable environment perspective faculty of education students' determination of levels of environmental literacy (Unpublished master's thesis). Afyon Kocatepe Üniversitesi, Eğitim Bilimleri Enstitüsü, Afyonkarahisar.

Büyüköztürk, Ş. (2020). Sosyal Bilimler İçin Veri Analizi El Kitabı. Ankara: Pegem Akademi.

Daudi, S. Sabiha (2000). Exploring environmental literacy in low-literate communities of Pakistan: a descriptive study to recommend strategies for planning environmental education programs, (Unpublished doctoral dissertation). University of Ohio State, U.S.

Delice, A. (2015). Karma Yöntem Desen Seçimi, Y. Dede ve S.B. Demir (Çeviri Editörleri). Karma Yöntem Araștırmaları Tasarımı ve Yürütülmesi. İkinci Baskı. Ankara: Anı Yayıncllık, ss. 61-116.

Ergün, M. (2019). Eğitim Felsefesi. Ankara: Pegem Akademi.

Erten, S. (2004). Çevre eğitimi ve çevre bilinci nedir, çevre eğitimi nasıl olmalıdır? Çevre ve İnsan Dergisi, Çevre ve Orman Bakanlığı Yayın Organı. Sayı 65-66. 
Fettahlıoğlu, P. (2018). Analysis of the percieved environmental problems according to environmental literacy levels. Mersin University Journal of the Faculty of Education, 14(1), 404-425.

Gürbüz, H., Kışoğlu, M., Alaş, A. Ve Sülün, A. (2011). Biyoloji öğretmeni adaylarının çevre okuryazarlıklarının farklı değişkenler açısından incelenmesi. E-International Journal of Educational Research, 2(1), 1-14.

Güler, Ç. ve Vaizoğlu, S.A. (2011). Turizm ve Çevre. Ankara: Yazıt Yayıncılık.

Hares, M., Eskonheimo, A., Myllyntaus, T. and Luukkanen, O. (2006). Environmental literacy in interpreting endangered sustainability case studies from Thailand and the Sudan. Geoforum. 37, 128-144.

Karatekin, K. ve Aksoy, B. (2012). Examination of teacher candidates of social studies' environmental literacy level in terms of various variables, Turkish Studies International Periodical For The Languages, Literature and History of Turkish or Turkic, 7(1), 1423- 1438.

Karatekin K. (2011). The determination of environmental literacy levels of pre- service teachers of social studies, (Unpublished doctoral dissertation). Gazi Üniversitesi Eğitim Bilimleri Enstitüsü, Ankara.

Karatekin, K. ve Yılmaz, A. (2019). Çevre Okuryazarlığı. Aksoy, A., Akbaba, B., ve Kılcan, B., (Editörler), Sosyal Bilgilerde Beceri Eğitimi içinde (25-52). Ankara: Pegem Akademi.

Kışoğlu, M., Gürbüz, H., Sülün, A., Alaş, A., ve Erkol, M. (2010). Environmental literacy and evaluation of studies conducted on environmental literacy in Turkey. International Online Journal of Educational Sciences, 2(3), 772-791.

Kocalar, A.O. ve Balcl, A. (2013). The environment literacy levels of prospective geography teachers, International Journal Social Science Research, 2 (2), 15-49.

Koç, A., Çorapçıgil, A., ve Doğru, M. (2018). Fen bilgisi öğretmen adaylarının çevre okuryazarlık düzeylerinin incelenmesi. Eğitim ve Yeni Yaklaşımlar Dergisi, 1(1), 39-52

Koç. H. ve Karatekin, K. (2013). An investigation into geography teacher trainees' environmental literacy levels with respect to various variables, Marmara Coğrafya Dergisi, (28), 139-174

Kışoğlu, M. (2009). Investigation the effect of student centered instruction on prospective teachers' environmental literacy, (Unpublished doctoral dissertation). Atatürk Üniversitesi Fen Bilimleri Enstitüsü, Erzurum.

MEB. (2018). Sosyal Bilgiler Dersi Öğretim Programı İlkokul ve Ortaokul 4,5,6, ve 7. Sınıflar. Ankara.

Miles, M. \& Huberman M. (1994). Qualitative data analysis: An expanded sourcebook, (2nd Edition),California: Sage Press.

Owens, M.A. (2000). The environmental literacy of urban middle school teachers, (Unpublished doctoral dissertation). Faculty of the Graduate School of Emory University, USA.

Özey, R. (2009). Çevre Sorunları. Aktif Yayınevi: İstanbul.

Özyürek, C., Demirci, F., Güler, H., Sarıgöl, J., Tepe, B. ve Çetinkaya, M. (2019). Investigation of pre-service teachers' environment literacy componenets by diffrent variables, Mehmet Akif Ersoy Üniversitesi Eğitim Fakültesi Dergisi, (50), 227-253.

Yılmaz, B. (1989). Okuryazarlık ve okuma alışkanlığı üzerine. Türk Kütüphaneciliği 3(1), 4853. 
Roth, C. E. (1968). Curriculum owerwiev for developing environmentally literate citizens. (ERIC Reproduction Service No. ED 032982).

Roth, C.E. (1992). Environmental literacy: Its roots, evolution and directions in the $1990 \mathrm{s.}$ (ERIC Reproduction Service No. ED 348 235).

Şahin, S., Ünlü, E., ve Ünlü, S. (2016). Investigation of teacher candidates'environmental literacy awareness level. Education Sciences, 11(2), 82-95.

Şenyuva, E., ve Bodur, G. (2016 Views of university students regarding nuclear plants and their levels of environmental literacy. Journal of Kirsehir Education Faculty, 17(1), 1937.

Timur, S. (2011). Determining environmental literacy levels of preservice science teachers, (Unpublished doctoral dissertation). Gazi Üniversitesi Eğitim Bilimleri Enstitüsü, Ankara.

Uyanık, G. (2016). Investigation of the attitudes towards environmental issues and knowledge levels of prospective teachers. Online Fen Eğitimi Dergisi, 1(1), 30-41.

\section{Biographical Statement}

Mavi AKKAYA YILMAZ is an Assistant Professor in the Department of Turkish and Social Studies Education at the Aydın Adnan Menderes University in Turkey. Her research interests focus on entrepreneurship, culture and cultural heritage, communication skills and using place-based education method in social studies education . 